\author{
A.B. Karabassova ${ }^{1 *}$ (D) , A.B. Abylkassymova ${ }^{2}$ \\ ${ }^{1}$ Al-Farabi Kazakh National University, Kazakhstan, Almaty \\ ${ }^{2}$ Kazakh University of International Relations and World languages named Ablai khan, Kazakhstan, Almaty \\ *e-mail: asselkarabassova@gmail.com
}

\title{
THE PRACTICAL SIGNIFICANCE OF XI JINPING'S CONCEPT OF SHARED DEVELOPMENT
}

At different stages of Development, Society has different development goals, themes and priorities. China continues its socialist modernization, while maintaining Chinese specifics in choosing development paths and Planning Development Strategies. At different stages of development, China set different development goals and was guided by different development concepts.

In his opening speech to the Nineteenth Party Congress on October 18, 2017, Xi Jinping noted the creation of the fully mature xiaokang (小康社会) society as the first of the four strategies of the «new era of socialism with Chinese characteristics», which official translators translate as «moderately prosperous society». One of the main tasks of a mature society is the development of human capital. At this stage of China's development, people's development is at the forefront. To achieve this goal, five development concepts were proposed. These concepts cover the areas of economy, political and spiritual culture, education and science, i.e. innovation, openness, environmental development, coordination and shared development. This article describes the concept of shared development, which plays an important role in the in the formation of Xiaokang society, attempts are made to reveal the main aspects of the concept of shared development, to show its practical application and prospects in the construction of socialism with Chinese characteristics in the new era.

Key words: China, development, CPP, socialism, xiaokang, shared development, Datong.

\author{
А.Б. Карабасова ${ }^{*}$, А.Б. Абылкасымова² \\ 'Әл-Фараби атындағы Қазақ ұлттық университеті, Қазақстан, Алматы қ. \\ ${ }^{2}$ Абылай хан атындағы Қазақ халықаралық қатынастар және \\ әлем тілдері университеті, Қазақстан, Алматы қ., \\ *e-mail: asselkarabassova@gmail.com

\section{Си Цзиньпиннің бірлескен даму тұжырымдамасының} \\ практикамық маңызы
}

Аамудың әр түрлі кезеңдерінде қоғамда әр түрлі даму мақсаттары, тақырыптары мен басымдықтары болады. Қытай даму жолдарын таңдауда және даму стратегияларын жоспарлауда қытайлық ерекшеліктерді сақтай отырып, социалистік жаңғыртуды жалғастыруда. Аамудың әртүрлі кезеңдерінде Қытай өзінің алдына әртүрлі даму мақсаттарын қойып, әр түрлі даму тұжырымдамаларын басшылыққа алды.

2017 жылғы 18 қазанда ҚКП он тоғызыншы съезін ашқан сөзінде Си Цзиньпин ресми аудармашылар «орташа өркендеген қоғам» деп аударатын «қытайлық сипаттамалары бар социализмнің жаңа дәуірінің» төрт стратегиясының алғашқысы ретінде жан-жақты кемелденген сяокан (小康社会) қоғамының құрылуын атап өтті. Кемелденген қоғамның басты міндеттерінің бірі адамзат капиталын дамыту болып табылады. Қытай дамуының қазіргі кезеңінде алғашқы орынға адамдардың дамуын қойып отыр. Осы мақсатқа жету үшін дамудың бес тұжырымдамасын ұсынған болатын. Бұл тұжырымАамалар экономика, саяси және рухани мәдениет, білім және ғылым салаларын қамтиды, яғни, инновация, ашықтық, экологиялық даму, координация және бірлескен даму. Берілген мақалада Сяокан қоғамын орнатуда маңызды рөлге ие бірлескен даму тұжырымдамасы сипатталып, бірлескен даму тұжырымдамасының негізгі аспектілерін ашуға, жаңа дәуірдегі қытайлық сипаттамалары бар социализм құрылысында оның практикалық қолданысы мен перспективаларын көрсетуге талпыныс жасалған.

Түйін сөздер: Қытай, даму, КҚП, социализм, сяокан, бірлескен даму, датун. 


\author{
А.Б. Карабасова ${ }^{*}$, А.Б. Абылкасымова² \\ ${ }^{1}$ Казахский национальный университет им. аль-Фараби, Казахстан, г. А^маты \\ ${ }^{2}$ Казахский университет международных отношений и \\ мировых языков имени Абылай хана, Казахстан, г. Алматы \\ *e-mail: asselkarabassova@gmail.com \\ Практическое значение \\ концепции совместного развития Си Цзиньпина
}

\begin{abstract}
На разных этапах развития общество имеет разные цели, темы и приоритеты развития. Китай продолжает социалистическую модернизацию, сохраняя китайские особенности в выборе путей развития и планировании стратегий развития. На разных этапах развития Китай ставил переА собой разные цели развития и руководствовался различными концепциями развития.

В своем выступлении на Аевятнадцатом съезде партии 18 октября 2017 года Си Цзиньпин отмети^ создание всесторонне развитого общества сяокан (小康社会) как первой из четырех стратегий «новой эры социализма с китайскими характеристиками», которые официальные переводчики переводят как «умеренно процветающее общество». ОАной из главных задач общества сяокан является развитие человеческого капитала. Китай на нынешнем этапе развития ставит на первое место развитие ^юдей. А^я достижения этой цели было преАложено пять концепций развития. Эти концепции охватывают сферы экономики, политической и Ауховной культуры, образования и науки, т. е. инновации, открытость, экологическое развитие, координацию и совместное развитие. В данной статье описана концепция совместного развития, которая играет важную роль в установлении общества сяокан, предпринята попытка раскрыть основные аспекты концепции совместного развития, показать ее практическое применение и перспективы в строительстве социализма с китайскими характеристиками новой эпохи.
\end{abstract}

Кмючевые слова: Китай, развитие, КПК, социализм, сяокан, совместное развитие, Аатун.

\section{Introduction}

At different stages of development, society has different tasks, themes and priorities. China continues socialist modernization while maintaining its Chinese characteristics in choosing its development path and planning strategies. In the process of modernizing its society, China has set itself different tasks and is guided by different concepts of development.

At the 5th Plenary Session of the 18th CPC Central Committee of the 18th Convocation held in Beijing on October 26-29, 2015, Chinese President Xi Jinping for the first time adopted five development concepts based on shared development, representing universal access to the fruits of innovation, coordination, ecology, transparency and development. offered. According to Chinese politicians and economists, the concept of shared development reflects the essence of socialism with Chinese characteristics in the new era and is the core and goal of the new concept of development.

Shared development is the pursuit of common prosperity and the promotion of all-round development of mankind. It also means achieving human development, human-based development and development success that people can share. (Jintao, 2007). The understanding of shared development should go beyond the simple category of economic growth and instead contribute to the ultimate goal of comprehensive human development in three areas: economics, society and politics.

As for the characteristics of different stages of modern human development, China is moving from a limited stage of shared development aimed at economic growth to a stage of shared development aimed at social construction. This period is characterized by the rapid development of social innovation and a significant increase in the potential of national governance, which helps to provide a systematic guarantee for the implementation of shared development.

Justification of the choice of article and goal and objectives

Like every nation in the world, the Chinese people have a dream: to live happily and well. The goal of the Chinese government is to realize the socialist modernization of China. According to Chinese leaders, the CCP's historic mission is to fulfill the Chinese dream and revive the Chinese nation. The questions facing today's Chinese leaders are: how to implement socialist modernization after the experience of backwardness and decline? How can China contribute to the long-term development of human potential? In response to these questions, Chinese President Xi Jinping proposed five concepts of development. Among these concepts, the concept of shared development is considered as the main tool of a fully developed society (全面 小康 社会). The main purpose of this article is to describe the con- 
cept of shared development, the task of the study is to reveal the main aspects of the concept of shared development, as well as to show its practical application and prospects in building socialism with Chinese characteristics in the new era.

\section{Scientific research methodology}

The systematic approach is the methodological basis of this research. The article presents a systematic approach to the formation and improvement of the social system of China, as well as general scientific methods such as analysis and generalization, analyzes and reflects on the views of Western, domestic and Chinese scientists on China's comprehensive society. At the same time, general scientific and special historical research methods were used to study in more detail the concepts of Chinese leaders in terms of historical development. The methodology of statistical and economic research has also been used to monitor and describe the dynamics of China's economic development over the past 30 years.

\section{Results and discussion}

The emergence of the concept of shared development. The concept of shared development includes the following aspects: First, it originates from the depths of Chinese culture and reflects the views of ancient Chinese philosophers on a perfect society. In traditional Chinese culture, concepts such as "Little Prosperity" (小康, Xiaokan), “Great Unity” (大同, Datong) fully reflect the aspirations of the Chinese people for a good, happy, prosperous life, and the concept of shared development is based on these concepts.

The concept of Datong and Xiaokan first appeared in the chapter "Li Ji" (礼记, “Notes on the Rules of Etiquette") of the canon "Li Yun" (礼 运, "Effectiveness of Superstition" or "Appeal to Goodness") (Martynov, 2011).

The Xiaokang principle reflects the issues of a partially just government. The great Chinese philosopher Confucius explained this principle as follows: Xiaokang is a society in which duty (yi) and procedure (li) are decisive in the appointment of positions in government, the choice of regime, family and economic issues. In a general sense, the Xiaokang Society is a middle-class society, the first step towards achieving the goal of establishing the Datong Great Unity Society (Chen, 2014).

At the turn of the 19th and 20th centuries, Confucianism was reformed, and the leader of this reform, Kang Yuwei, explained the doctrine of the three epochs of historical development. explained (YouWei, 2012).
Second, the concept of shared development is the result of the attitude of the leaders of the previous generations of socialist China to socialism. 1970s During the period of reforms initiated by Deng Xiaoping, which began in the late 19th century, the prosperity associated with Xiaokan was identified as the goal of the four modernizations (四个 现代 化). In 1979, when talking to Japanese Prime Minister Masayoshi Ōhira about China's modernization, Deng Xiaoping used the concept of xiaokan to analyze China's development path: "The four modernizations we carry out are the four modernizations of China. Our concept of modernization is not the same as your concept of modernization, which is the Xiaoking family (小家家)”(Xiaoping, 1993). This concept and the principles of socialism are closely linked. At the 7th Plenum of the Central Committee of the CPC of the XIII convocation, it was decided to achieve the main task of economic construction in the 1990s - the level of Xiaokan. At the 16th Party Congress in 2002, Jiang Zemin announced that a “comprehensive xiaokang” (全面 小康) would be achieved by 2020 . This was confirmed by Hu Jintao in his speeches at the 17th and 18th Party Congresses in 2007 and $2012(\mathrm{Hu}, 2012)$. This goal later became a key part of Xi Jinping's final decision at the party's 19th congress in 2017, as he repeatedly declared a "decisive victory in achieving a comprehensive Xiaokan society" as his goal for the next five years. The results of the Five-Year Plan for the National Economy and Social Development of the People's Republic of China show that the average annual income has gradually increased and the number of the poor has decreased. The five-year plans are based on one of the basic principles: "People should live well." Here are some official data, the results of the five-year plans.

In October 2017, at the 19th Congress of the Communist Party of China, it was announced that the life of the general population has risen to the level of average income, that is, a prosperous society as a whole has been created. It was noted that this is an important transitional historical period, ie by 2020 the first two steps of the «three-stage» strategic goal will be completed. It is planned to move to the third step: to increase GDP per capita to the level of middle-income countries by the middle of the XXI century, to ensure that living standards are higher than the average living standard "(Syroezhkin, 2018). However, it was during this period that China faced a number of challenges, such as a complex international atmosphere, reforms, development and stability in the country, especially in the fight against COVID-19. 


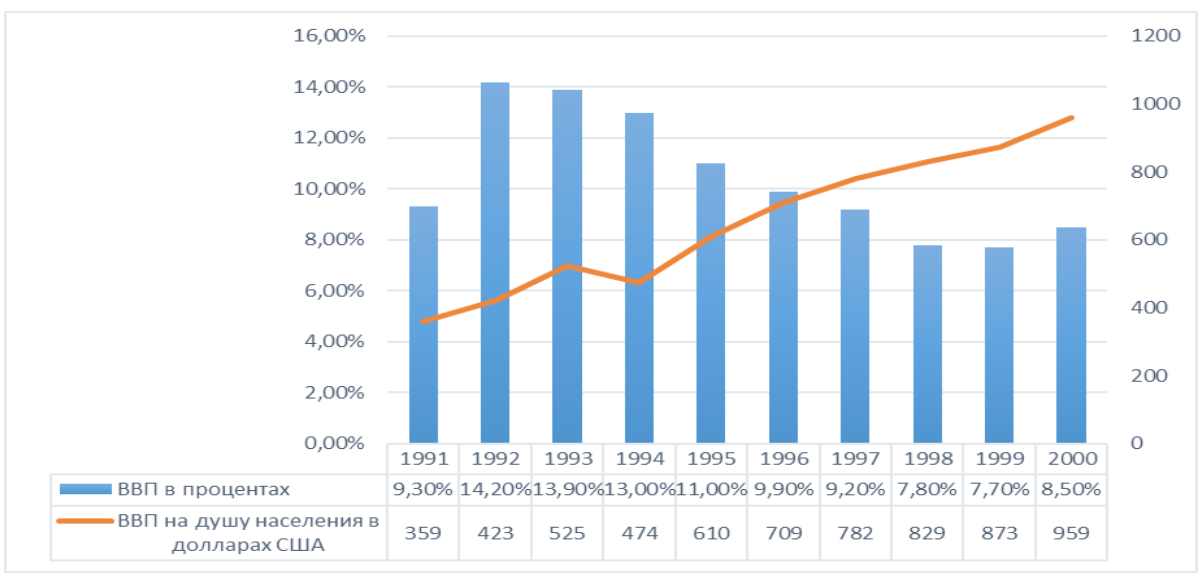

Figure 1 - GDP indicators for the 8-9 Five-Year Plan period (compiled by the authors according to the IMF, 2021)

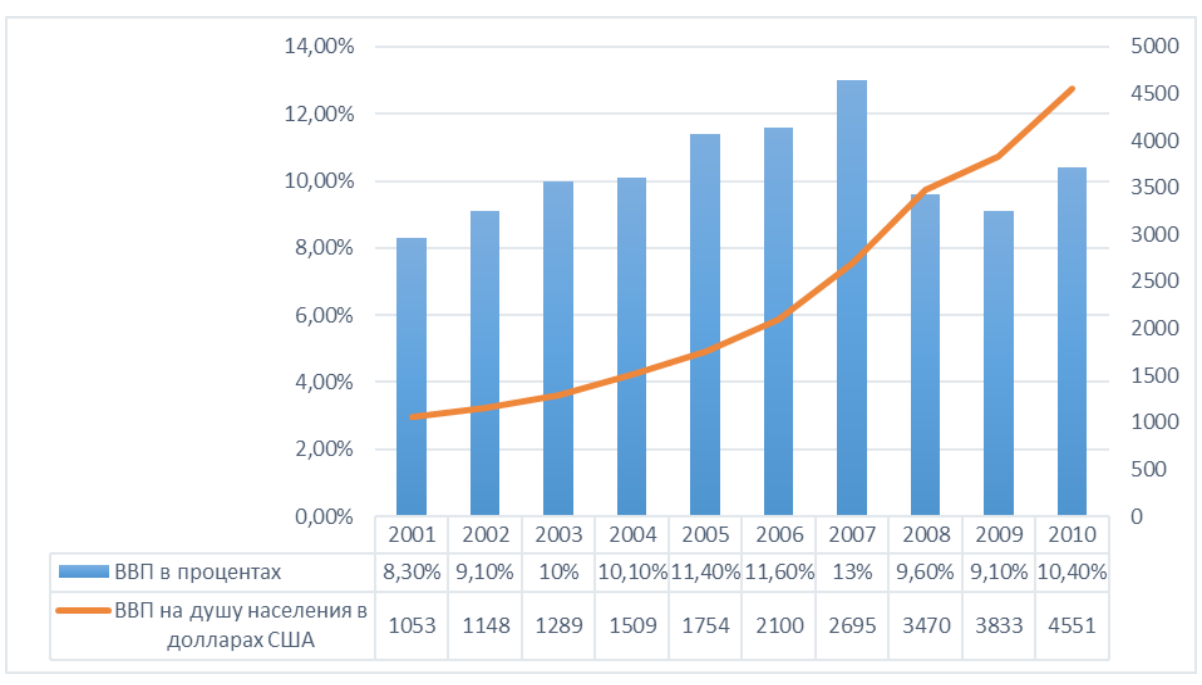

Figure 2 - GDP indicators for the 10-11 Five-Year Plan period (compiled by the authors according to the IMF, 2021)

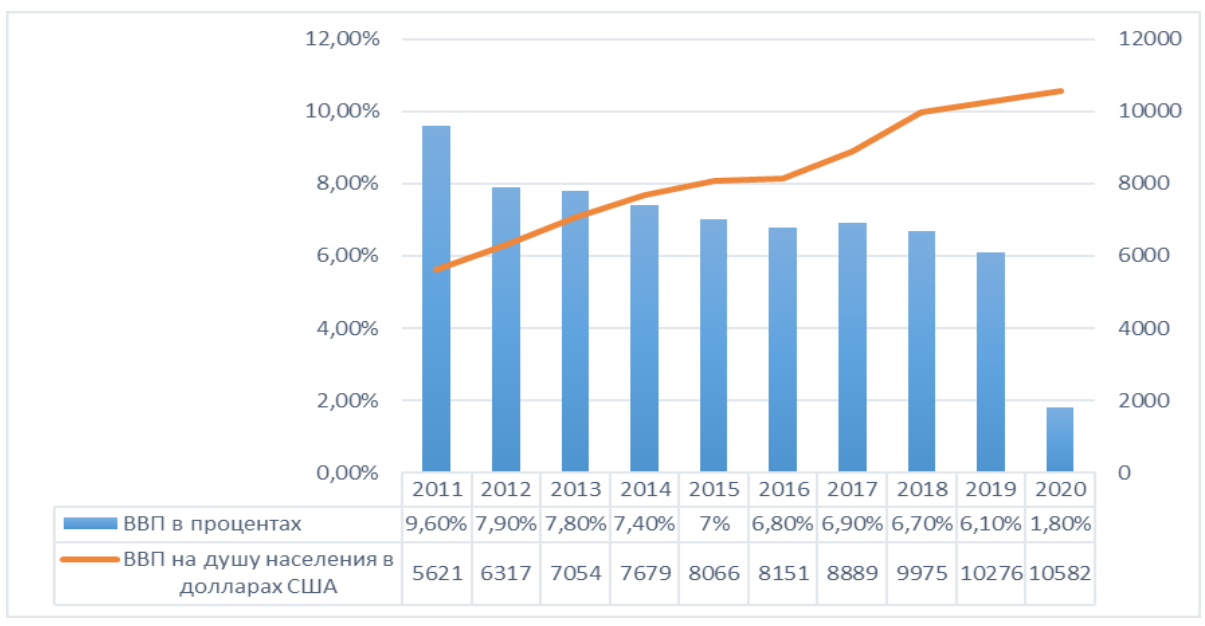

Figure 3 - GDP indicators for the 12-13 Five-Year Plan period (compiled by the authors according to the International Monetary Fund, 2021) 
The practical significance of Xi Jinping's concept of shared development

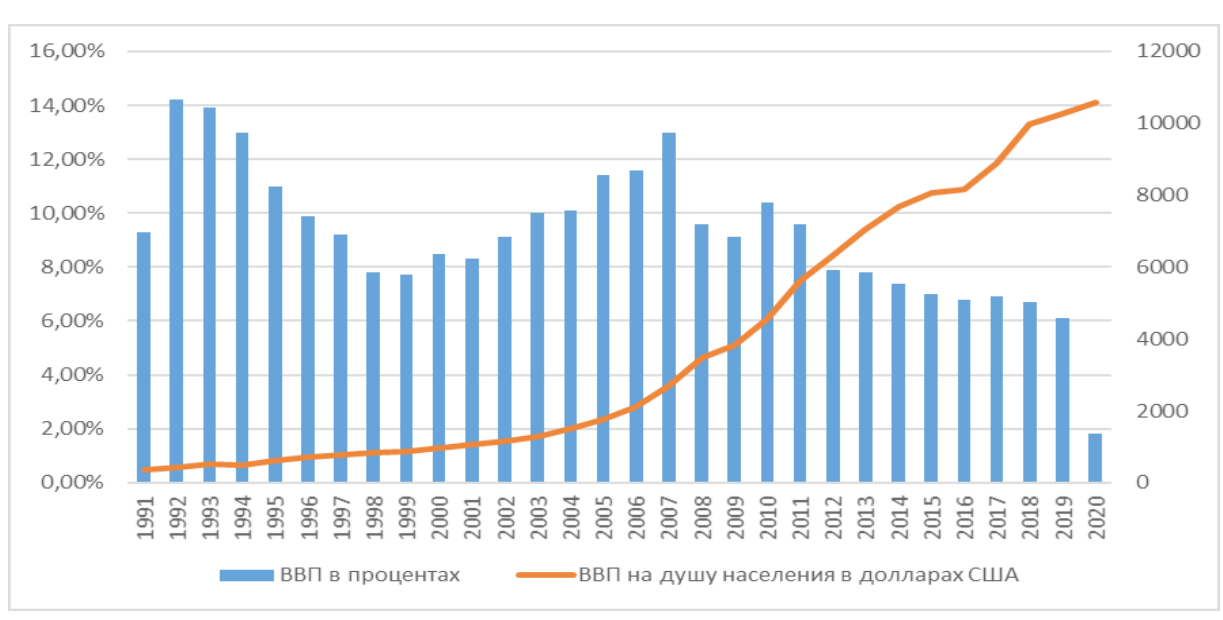

Figure 4 - GDP indicators for 1991-2020

(compiled by the authors according to the International Monetary Fund, 2021)

At the last meeting of the Politburo of the CPC Central Committee, it was noted that the 14th FiveYear Plan was a new stage in the comprehensive construction of a modern socialist country after China achieved its goal of building a full-fledged middle class society. It was also noted at the meeting that China is currently at a stage of strategic development opportunities and new changes are taking place in the near future, both in terms of opportunities and challenges (Kozhirova, 2020).

Necessity and importance of the concept of shared development

The demand for shared development and the constant pursuit of common prosperity are the foundation for building a comprehensive, moderately prosperous society, as well as creating a harmonious socialist society (Hu et al., 2011 p. 10). It has three important principles: 1) all people should make significant efforts for the comprehensive development of the economy and society and the joint creation of all types of wealth; 2) all people will receive planned benefits, participate collectively in China's development achievements, and work together on the path to prosperity; 3 ) all people will live in harmony, create a society together, everyone will be healthy and help each other.

The main goals of shared development are to reduce the regional development gap, reduce the income gap between rural and urban residents, increase family property, and ensure a rich life for people. In addition, the Chinese government is trying to reduce the relative gap between public services for residents of urban and rural areas and interregional regions, as well as reduce the relative gap between the main indicators of Social Development, intends to increase the opportunities for human capital and the development of the population in rural and undeveloped regions. According to the concept of joint development, it is important that rural residents are encouraged to move to cities and settlements, and residents of undeveloped regions to move to developed regions, where they are encouraged to participate in the development achievements of urban and developed regions and receive relevant public services (Hu et al., 2011 p. 112, 135). According to the Chinese leader, in the first half of 2021, the authorities will solemnly announce the construction of a moderately prosperous society in China, so that China enters a period of common prosperity. The sign of overall prosperity is the constant reduction of the three main gaps: the gap between urban and rural areas, the regional gap and the gap between people. These gaps are not only a gap in income, but also a gap in development in the broadest sense, which includes multidimensional indicators such as income, health, education and the level of public services. According to the principles of co-development, all, whether urban or rural, living in the east coast or in the inner provinces of the west, or they are workers or farmers, can all live relatively rich and receive relatively high quality public services. Covering the main social security groups, 1.4 billion people have equal access to the achievements of China's economic development.

Key aspects of the concept of shared development

Joint development is the main direction of China's socialist development and allows the society to share common aspirations. The Socialist Modernization of China is, in fact, the modernization of the people and the constant investment of billions of people in 
human capital, taking full advantage of the socialist system and the political system. It includes creating opportunities for human development, increasing human potential, stimulating the vitality of human development and creativity, and fully reflecting the new «people-oriented» requirements. In accordance with the new three-stage strategy of the CPC Central Committee, during the 13th Five-Year Plan period, the Chinese authorities accelerated the restructuring of China's economic and social development. Its main idea is not a one-sided, moderately prosperous society, but a comprehensive, moderately prosperous society. China is moving towards a period of general prosperity and is saying goodbye to a period when only a few segments of society became rich. Achieving this goal by 2021 provides an important basis for China to realize its centennial national dream. China is currently implementing two strategic national programs - «Two Century Goals»: the creation of a prosperous society by 2020 and the creation of a modern, rich and developed socialist country by 2049. The first goal was dedicated to the centenary of the founding of the Communist Party of China, and the second to the centenary of the founding of the People's Republic of China. Due to the coronavirus pandemic, the Chinese government failed to achieve its first goal by 2020, but the rapid recovery of the Chinese economy after the first wave of COVID-19 has given optimism to the Chinese leadership. Thus, China plans to reach a new level of development. This stage covers the following key aspects:

\section{Poverty Alleviation Plan}

The main task to celebrate the status of people in co-development is to implement the Poverty Reduction Plan for the 13th Five-Year Plan and to help poor areas through the creation of a comprehensive, moderately prosperous society. According to $\mathrm{Xi}$ Jinping, the most difficult and difficult task of building a prosperous society is to cover rural areas, especially the poor (许, 2020). It is impossible to create a prosperous society in rural areas, especially in poor areas, without moderate prosperity. Thus, the 13th Five-Year Plan period was considered as a crucial stage in the realization of the complex goal of building a prosperous society. The key to success or failure is the question of whether the desired prosperity can reach the village. Statistics show that in the 5 years from 2010 to 2014, the number of poor people in rural areas decreased by about 100 million (according to the new national poverty line). At the end of 2014, more than 70 million people were still living below the poverty line, but only a small group of the population was living in extreme poverty (李 萍 \& 韦宁 韦宁, 2020).
Therefore, the 5th Plenary Session of the 18th CPC Central Committee proposed planning requirements, according to which «according to current standards, poverty will be eliminated among the poor rural population of China, poverty in poor districts will be eliminated, and the problem of regional poverty will be solved.» According to the Chinese leadership, this issue will be resolved by 2021 through the creation of a comprehensive, moderately prosperous society. Thus, for the first time, development-oriented poverty reduction is becoming a priority. The main goal of poverty eradication during the 13th Five-Year Plan period was to implement poverty reduction measures based on targeted combating poverty and increasing the opportunities for rich areas to become rich and selfdevelopment among the poor. This is in line with the requirements of the «four practical points» proposed by Secretary-General Xi Jinping (ie, fulfilling the responsibilities of leadership, achieving targeted poverty reduction, strengthening social cohesion and strengthening lower organizations). The following describes a number of specific measures that need to be implemented.

In terms of organization and policy, poverty reduction resources will be integrated into different units at different levels, and a poverty reduction policy will be developed on the basis of links between central and local governments, the government and society. In terms of financial investment, efforts will be made to increase remittances to the old revolutionary base areas, ethnic minority areas, border areas and poverty areas. The necessary infrastructure and financial measures to reduce poverty will be systematically developed.

In terms of resources, efforts will be made to identify the causes of poverty in different regions, and China will provide targeted support to combat environmental, industrial and educational poverty. Measures to combat environmental poverty include increased environmental emigration and resettlement from difficult natural areas. To reduce industrial poverty, the Chinese government plans to assess the basic conditions and potential for industrial development of poor areas, provide targeted industrial support in accordance with local financing conditions, as well as focus on long-term returns and social benefits of industrial poverty reduction projects. Poverty reduction projects are also aimed at providing employment opportunities for the poor and avoiding economic development that harms the environment. The main focus on poverty reduction in education is to prevent «generational transmission of poverty», increase the level of basic 
education in poor areas, strengthen teacher training for basic education and ensure teacher exchange in other areas.

\section{Promotion of common prosperity between} urban and rural areas

The common prosperity of cities and villages is the integration of urban and rural areas, as well as the integration of a pluralistic social structure. It also reflects the eradication of poverty among the rural poor, the convergence of incomes and living standards in urban and rural areas. The average annual growth rate of average per capita income of urban and rural population was about $7.0 \%$. The 12 th Five-Year Plan exceeds 7\%. The average annual growth rate in 2011-2014 ranged from 8.0 to $10.1 \%$ (National Bureau of Statistics, 2015). Given this result, a similar experience was adopted during the 13th Five-Year Plan period to achieve synchronous growth in incomes and economic development, as well as incomes in rural areas.

\section{Promoting regional overall prosperity}

The imbalance of regional development is a key characteristic of China's national situation. Despite these differences, incomes are growing in all regions. Thus, the gap in regional development can be described by the term «One China, four worlds» (Hu, 2001). As China enters the 21st century, this model has undergone significant changes. In some regions, there is a steady increase in income, as well as convergence. This means the transition from the original «four worlds» to the current «two worlds» (that is, by 2020, when China's overall level is close to the level of high and middle income countries, about half of the provinces (cities, regions) have reached high incomes, and the other half After 2021, China intends to continue its development from «two worlds» to «one world», ie to raise the income level of the population in all regions of China to a higher level.

The most important is the continuous improvement of HDI (Human Development Index). From the point of view of international comparison, HDI is the best indicator of the level of development of a country or region. The index is compiled and published by the United Nations and used in 188 countries and regions around the world. As the world's most populous country, China must adopt this index to objectively assess its level and quality of development. According to the United Nations Development Programme's 2015 Human Development Report, China's HDI in 2014 was 0.727 , ranking 90th out of 188 countries. In China, the average life expectancy was 75.8 years, secondary education was 7.5 , the estimated school years were 13.1, and GDP per capita was $\$ 12,547$, which means a high level of human development. (The country's HDI should be higher than 0.700.) China's HDI in 2020 was 0.761 , ranking 85th out of 188 countries.

\section{Equalization of basic services}

The comprehensive human development depends not only on the level of economic development of the country, but also on the level of provision and equalization of basic public services. During the 13th Five-Year Plan period, China focused on equalizing key public services. This has become the main task of scientific and harmonious development and the main responsibility of the government at all levels. Equalization of basic public services means that people have equal rights and can enjoy public services as equally as possible. Ensuring the balance of key public services is the main task of the current government. Today, the government must ensure that all members of society - whether urban or rural, living in developed or poor areas, or belonging to different social groups - have access to a variety of basic public services on a relatively equal and equitable basis. Such services include compulsory education, public health and basic health care, social security, employment services and basic housing. China intends to work to create and improve a sustainable civil service system that meets national conditions. The system covers mainly urban and rural areas, and also aims to gradually reduce the gap between living standards and public services in urban and rural areas. Equalization of public services emphasizes the equality of opportunities and results, rather than the simple lack of balance and differentiation.

\section{Speed up education modernization}

During the 12th Five-Year Plan period, the share of budget expenditures on education in GDP was constantly increasing. This period was also marked by the successful implementation of the main objectives of education development proposed in the State 12-Year Plan. The rate of concentration of compulsory education has reached $93 \%$, and the rate of enrollment in secondary schools has reached $87 \%$, which is close to the target of $2020-90 \%$. The overall rate of higher education coverage reached $40 \%$, which allowed to achieve the goal of 2020 ahead of schedule. This demonstrates China's significant progress in modernizing education and further narrows the gap between China's key indicators of education development and those of developed countries.

Accelerating the modernization of education means recognizing education as a key element of 
modernization and ensuring the «right to education» for society as a whole, especially for those seeking education. It also means constantly increasing the level of human capital and development opportunities. Only through the modernization of education can China make a radical contribution to the modernization of billions of Chinese, and then modernize China. According to the National Plan for the Reform and Development of Medium and Long-Term Education (2010-2020), the overall goal of education development in the 13th Five-Year Plan period is as follows: "By 2020, China will mainly modernize education, build a learning society and human resources. is included in the world ranking of rich countries. China seeks to build a society of continuous learning with an advanced system and a country with a high level of human resources. To achieve this goal, China must continue to deepen education reform, increase investment in education and, under the leadership of the government, establish sustainable public education supply and mechanisms. This will allow several entities to participate and raise funds through various channels with public funding. This strategy includes topdown and bottom-up public relations. This can be achieved by improving the quality of education in China, guaranteeing the right to education for children from low-income groups, promoting fair education and promoting higher education.

\section{Mass employment}

$\mathrm{Xi}$ Jinping has repeatedly stressed that «employment is very important for people's lives.» Full employment is one of the most important goals of national governance in China. The solution to the problem of employment is directly related to the large population of China. However, the large population also contributes to the current progress in creating more jobs. During the 12th Five-Year Plan period, it took China only four years to achieve its planned goal of creating an additional 45 million jobs in cities and towns (2011-2015). The scope of work was varied and this goal was achieved ahead of schedule. This achievement has helped to optimize the employment structure and to cover the majority of workers in the service sector. This has led to the creation of an employment structure in China, which is the main service sector.

\section{Social security for all of China}

Creating a social security system is one of the most complex, difficult and important issues in the world. Low levels of social protection are a major obstacle to the overall improvement of human development around the world. During the 13th Five-Year Plan period, China adhered to the basic concept of «urban and rural integration, improving quality and systems, and promoting justice.» At the same time, China intends to continue its social security policy and accelerate the establishment of a strong social security system with Chinese characteristics.

\section{Conclusion}

Shared development is the creation of a socialist modernization society with Chinese characteristics, created by people under the leadership of the CCP. It is a process of constant assimilation, diffusion and application of modern factors, and this process allows to modernize the whole society. Shared development is an innovative Chinese-style innovation using traditional cultural and historical resources, collective innovation and multi-generational innovation. The Fifth Plenum of the Central Committee of the CCP of the 18th convocation put «people's status» at the forefront of its six basic principles. These are the principles that need to be followed in order to achieve the goal of creating a comprehensive, moderately prosperous society. Thus, the status of people is an important aspect of co-development aimed at achieving human development, peoplebased development and achievements in the field of common human development. This will allow people to feel the great benefits of China's joint construction and joint development. The demand for joint development provides a legal and institutional framework for broad social innovation and gives a new impetus to China's medium and high-speed economic development. Thus, China will avoid the «middle income trap». Co-development will help improve people's living conditions and create a comprehensive, moderately prosperous society.

According to $\mathrm{Hu}$ Angang, a leading Chinese economist, China's entry into a new era means, first, the transition from the era of a great power to the era of a world superpower. Second, it aims to move from the era of «dominant prosperity» (according to Deng Xiaoping's formula, which allows the first enrichment of parts of people and parts of regions) to the era of «general prosperity». Using the concept of joint development as a key tool, the Chinese government, under the leadership of the $\mathrm{CCP}$, is trying to cover all of the above aspects. However, in the process of long-term planning, it is necessary to take into account the internal and external factors that hinder its implementation. For example, the 19th CPC National Congress in 2017 called for the eradication of poverty among rural people living below the poverty line by 2020 
$(2,300$ yuan per year), the removal of the «poor» label from all poverty-stricken districts, and the end of regional poverty. was planned, but as mentioned above, this plan was postponed to mid2021. Factors influencing it include trade wars between the United States and China, which have slowed China's economic growth since 2018, as well as the COVID-19 pandemic, which began in China in late 2019 and has spread around the world since early 2020. was a blow. We all know that in times of economic downturn, it is impossible to fully address social issues. The world's most populous country has a utopian and ambitious plan to provide mass employment, education and a prosperous standard of living. However, the fact that the Chinese economy is one of the first to recover from the COVID-19 pandemic compared to other countries is also optimistic.

\section{References}

Hu, J. Doklad Hu Jintao Na 17-m S”yezde KPK (Polnyy Tekst) [Hu Jintao's Report to the 17th CPC Congress (Full Text)], russian.china.org.cn/china/archive/shiqida/2007-10/25/content_9120930.htm.

Martynov, D. E. (2011). Konfutsianskiy ideal Velikogo Yedineniya: reinterpretatsiya i problema perevoda. [The Confucian Ideal of the Great Unity: Reinterpretation and the Problem of Translation]. Scientific notes of Kazan University. Humanities Series, 153 (1), pp. 78-88.

Chen, Albert H.Y. (2014). 'The Concept of “Datong” in Chinese Philosophy as an Expression of the Common Good.' In The Common Good: Chinese and American Perspectives, edited by D. Solomon and P.C. Lo, 85-102. Dordrecht: Springer.

Kang, Y. (2012). Book of Great Harmony. China Pictorial Publishing House.

Deng, X. (1993). Development of Sino-Japan Relations Shall See Further. In Collected Works of Deng Xiaoping (Vol. 3, p. 53). China: People's Publishing House.

Syroyezhkin, K. (2018). Kitay posle XIX s"yezda KPK: novyy balans sil. [China after the 19th CPC Congress: A New Balance of Power]. Research Institute of International and Regional Cooperation of the Kazakh-German University.

Kozhirova, S. B. (2020). Pyatyy plenum TSK KPK 19-go sozyva (26-29 oktyabrya 2020 g.) i dolgosrochnyye perspektivy kitayskoy ekonomiki. [Fifth Plenary Session of the 19th CPC Central Committee (October 26-29, 2020) and the long-term prospects of the Chinese economy]. International Scientific Complex "Astana". https://isca.kz/ru/analytics-ru/3588.

Hu, A. G., Yang, Y. L., \& Wei, X. (2011). 2030 China: Towards A Common Prosperity. China Renmin University Press.

Xǔjítuán. (2020). Lùn xíjìnpíng gòngxiăng fāzhăn lǐniàn de zhéxué yìyùn yǔ shídài yìyì [On the philosophical implication and contemporary significance of Xi Jinping's concept of shared development]. Journal of Kashgar University (05), pp. 14-17.

Lǐ píng\& wéi níng wèi. (2020). Hòu fúpín shídài wǒguó xiāngduì lùjìng qiánzhān [Looking forward to my country’s relative path in the post-poverty alleviation era]. Local Finance Research (10), pp. 71-81.

Hu, A. G. (2001). Region and Development: New Strategy of Western Development. China Planning Press.

National Bureau of Statistics: 2015 China Statistical Abstract, pp. 58 and 60, China Statistics Press,

Human Development Reports. | Human Development Reports. http://hdr.undp.org/en/countries/profiles/CHN. 